\title{
The Research of Treg Cells: Progress and Challenge
}

\author{
Jinguo Zhu1,2 \\ ${ }^{1}$ Department of Cardiothoracic Vascular Surgery, People's Hospital of Sanya City, Sanya, China \\ ${ }^{2}$ Department of Cardiovascular Surgery, Lanzhou University Second Hospital, Lanzhou, China \\ Email: zsig2009@163.com
}

Received 12 March 2015; accepted 22 June 2015; published 25 June 2015

Copyright (C) 2015 by author and Scientific Research Publishing Inc.

This work is licensed under the Creative Commons Attribution International License (CC BY). http://creativecommons.org/licenses/by/4.0/

(c) ()

\section{Abstract}

$\mathrm{T}$ regulatory cells (Tregs) play an important role in the induction and maintenance of immunological tolerance to self and alloantigens. Recent findings in experimental transplant models have demonstrated that Treg could control and delay allograft rejection. Induction of immune tolerance decreases the risk of acute and chronic graft rejection after solid organ transplantation and can improve transplanted organ survival. Tregs are being tested in trials as a potential therapy in cell and solid organ transplantation. However, as we know, regulatory $T$ cells (Tregs) are crucial for peripheral tolerance and are intimately involved in cancer. The influence of Tregs on cancer progression has been demonstrated in a large number of preclinical models and confirmed in several types of malignancies. Neoplastic processes trigger an increase of Treg numbers in draining lymph nodes, spleen, blood, and tumors, leading to the suppression of anti-tumor responses. In this review, we summarize some of the critical aspects of the immunoregulatory function of Treg cells in cancer and transplantation and discuss their potential research progress and challenge.

\section{Keywords}

Treg Cells, Transplantation Immunoregulatory, Cancer Immunoregulatory

\section{Introduction}

Recently, characteristic and function of Treg cells research achieved significant progress. Especially, its role in immune tolerance has been confirmed by more and more experiment [1]-[5]. However, because of its immunosuppression, the influence of Treg cells on cancer progression has been demonstrated in a large number of preclinical models and confirmed in several types of malignancies [6]-[11]. How to deal with the Treg cells in the 
balance between transplantation tolerance and cancer? Here, we discuss the progress of Treg cells and comment on their challenge between immune tolerance and cancer.

\section{Origin and Characteristic of Tregs}

\subsection{Origin of Tregs}

Treg cells originate from thymus, being called natural Treg cells. These cells move to periphery to exert their roles [12]-[18]. In the periphery, these cells can be emigrated from thymus or differentiated in the local places [19]-[26]. Thus, Treg cells can be classified into natural (nTreg) and induced Treg (iTreg) cells [27]-[31] (Figure 1). Several different types of regulatory $\mathrm{T}$ cells exist which are classified into two major subgroups, natural regulatory $\mathrm{T}$ cells produced by the thymus and adaptive regulatory $\mathrm{T}$ cells that are induced in the periphery upon antigenic stimulation of naive T cells under tolerogenic conditions (such as TGF- $\beta$, IL-10 and immature DC). Thymus-derived CD $4^{+} \mathrm{CD} 25^{+} \mathrm{Foxp}^{+}$Treg cells, DN and some subsets of CD8 suppressor cells can also develop in the periphery. Abbreviations: nTreg-naturally occurring $\mathrm{CD}^{+} \mathrm{CD}_{2} 5^{+} \mathrm{Foxp}^{+}$Treg cells; iTreg—induced $\mathrm{CD}^{+}{ }^{+} \mathrm{CD} 25^{+} \mathrm{Foxp}^{+}$Treg cells; NKT—natural killer T cells; DN—double negative Treg cells; Th3-T helper type 3; Tr1-type 1 regulatory T cells [32]-[39] (Figure 2 from Itay Shalev et al.).

\subsection{Characteristic and Function of Tregs}

Regulatory $\mathrm{T}$ cells are suppressive $\mathrm{T}$ cells that have an essential role in maintaining the balance between immune activation and tolerance. The induction and maintenance of immune tolerance to transplanted tissues constitute an active process involving multiple mechanisms that work cooperatively to prevent graft rejection.

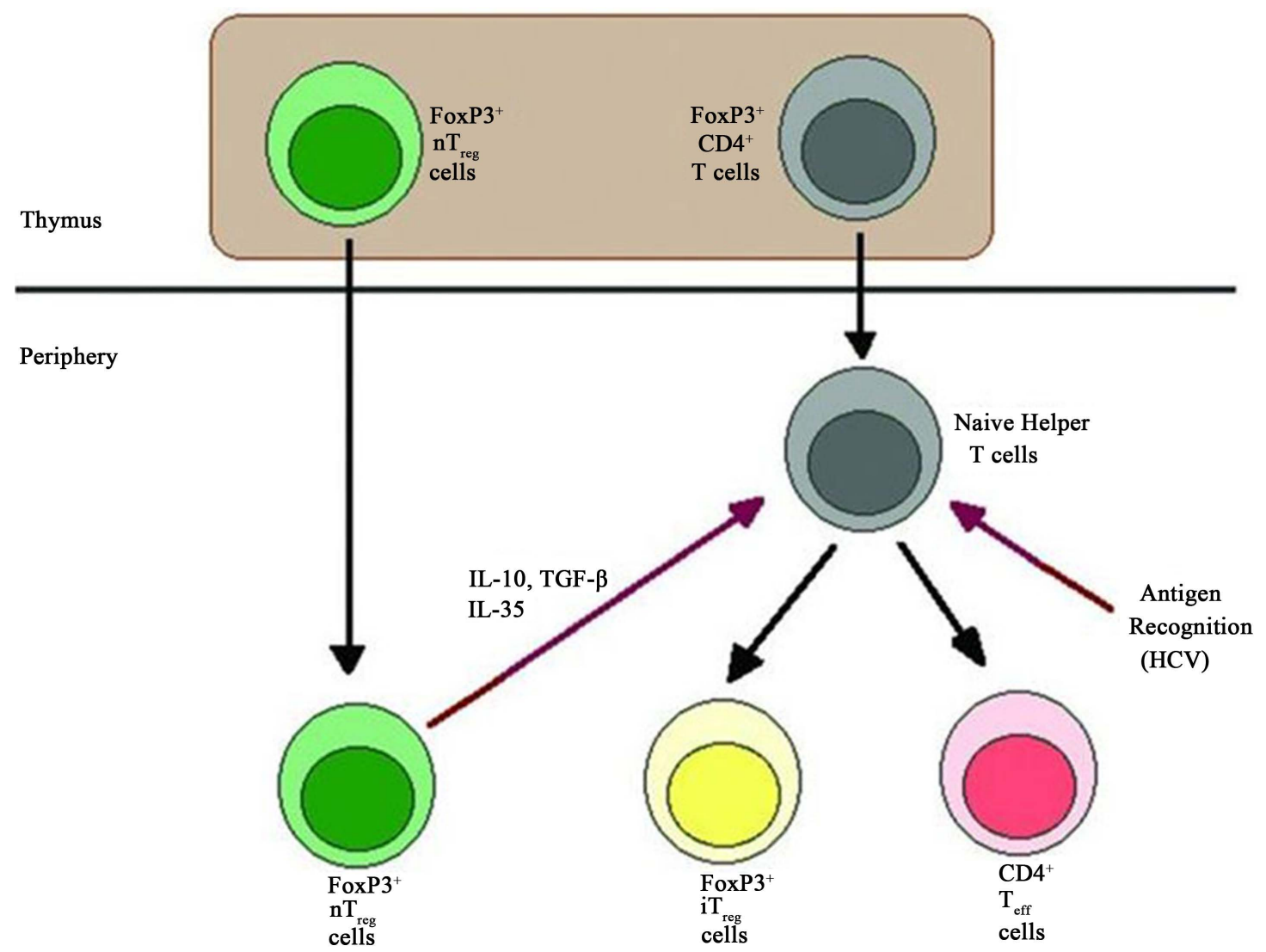

Figure 1. Origin and classification of Treg cells. Treg cells production in the thymus and periphery. Natural (n) Treg cells are generated by high-avidity selection in the thymus. Inducible (i) Treg cells derive from antigenstimulated naïve $\mathrm{T}$ cells in the periphery. nTreg cells can promote iTreg cells development by cytokine-dependent mechanisms. 


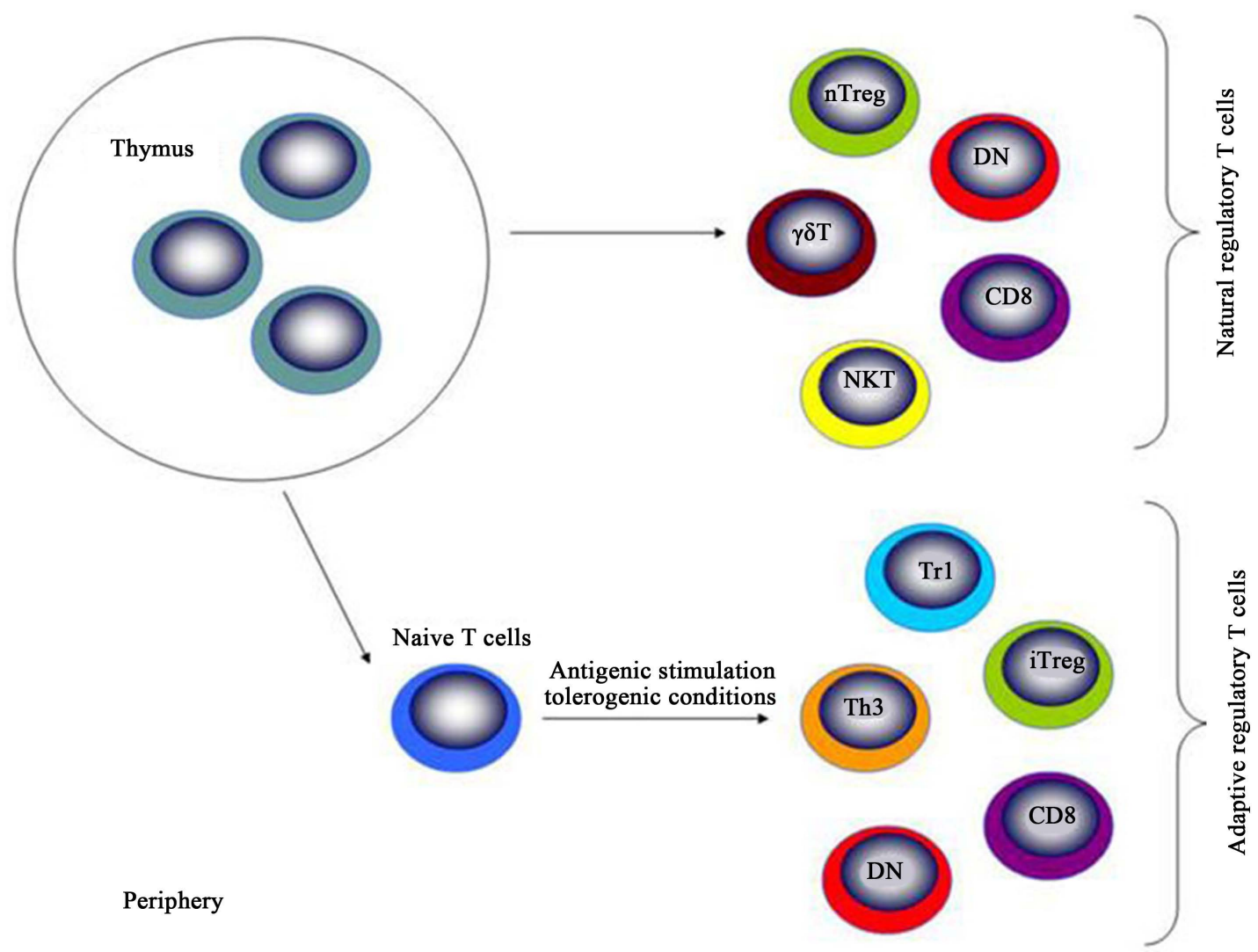

Figure 2. Natural and adaptive regulatory T cells. Natural regulatory $\mathrm{T}$ cells produced by the thymus and adaptive regulatory $\mathrm{T}$ cells that are induced in the periphery upon antigenic stimulation of naive $\mathrm{T}$ cells under tolerogenic conditions.

These mechanisms are similar to inherent tolerance toward self antigens and have a requirement for active immunoregulation, largely $\mathrm{T}$ cell mediated, that promotes specific unresponsiveness to donor alloantigens. The major target for Treg cells is T cells, Nonetheless, recent studies have also demonstrated that Treg cells also exert their effects on B cells and other cells including mast and Veto [40]-[46]. Suppressive mechanisms of Tregs for $\mathrm{T}$ cells can be divided into three categories: cell-cell contact, local secretion of inhibitory cytokines and local competition for growth factors (Figure 3 from Dorothy K Sojka et al.) [47]. In each category there are multiple examples of inhibitory pathways that are probably not mutually exclusive. Treg cells can suppress B cell responses and control B cell-mediated diseases (Figure 4 from Lim HW et al.) [48]. evidence is provided through studying the patients with IPEX (immune dysregulation, polyendocrinopathy, enteropathy, X-linked) patients who lack Treg cells. Multiple and diverse autoantibodies are commonly identified in the sera of IPEX patients, suggesting that Tregs represent a key regulator for autoreactive B cells [49]-[53]. FOXP3 deficiency resulted in the accumulation of autoreactive clones in the mature naive B-cell compartment of IPEX patients, providing direct evidence for the role of Tregs in maintaining B-cell tolerance [54]-[57]. At the same time, treg cells can suppress the activation, proliferation, differentiation and effector function of various immune cells, including $\mathrm{CD}^{+}$and $\mathrm{CD}^{+} \mathrm{T}$ cells, dendritic cells (DC) and natural killer cells [58] [59] via different mechanisms, depending on the target and location of their action.

\section{Tregs and Transplantation Immune Tolerance}

Regulatory T cells (Treg cells) offer potential for improving long-term outcomes in cell and organ transplantation. Multiple reports have established that activation of $\mathrm{CD}^{+} \mathrm{CD}^{+} 5^{+}$Tregs constitutes an essential element of the immunoregulatory pathways that create peripheral allograft tolerance [50] [60]-[64]. Lise Pasquet et al. reported that combine Treg cells infusion with bone-marrow transplantation to induce genuine immunological tolerance to donor tissues. The results demonstrated the clinical potential of Treg infusion in induction of bone- 


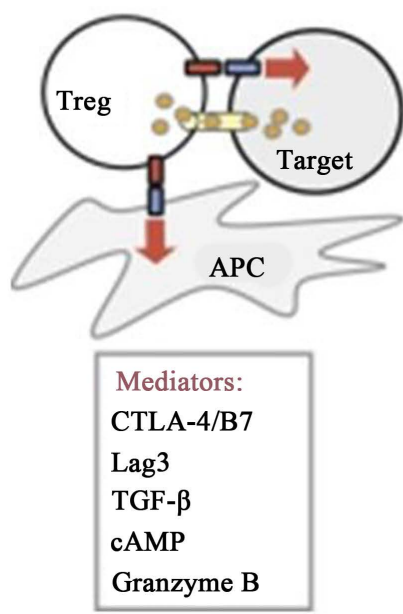

(a)

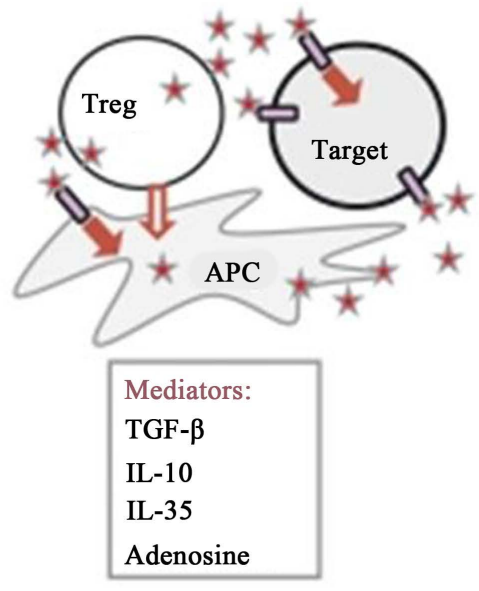

(b)

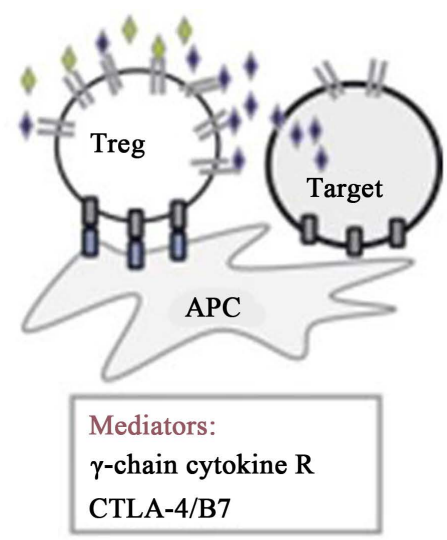

(c)

Figure 3. Mechanisms of regulatory T-cell (Treg) suppression. (a) Cell-cell contact. Tregs may suppress target cells via direct interaction of receptor-ligand pairs on Tregs and target cells; delivery of suppressive factors via gap junctions including cyclic adenosine monophosphate (cAMP); direct cytolysis; membrane-bound suppressive cytokines such as transforming growth factor- $\beta$ (TGF- $\beta$ ); and/or indirectly via modulating the antigen-presenting cell (APC) through cell-cell contact, possibly through reverse signalling via Treg-cytotoxic T-lymphocyte antigen-4 (CTLA-4) engagement of B7 on dendritic cells; (b) Soluble suppressive factors. Tregs can directly secrete interleukin-10 (IL-10), TGF- $\beta$ and IL-35 or induce APCs to secrete such factors. Expression of CD73/CD39 by Tregs facilitates the local generation of adenosine that can down-modulate immune function; (c) Competition. Tregs may compete for some cytokines that signal via receptors that contain the com mon $\gamma$-chain (IL-2, IL-4 and IL-7). Additionally they may compete for APC costimulation via constitutive expression of CTLA-4. Red arrow indicates an inhibitory signal.

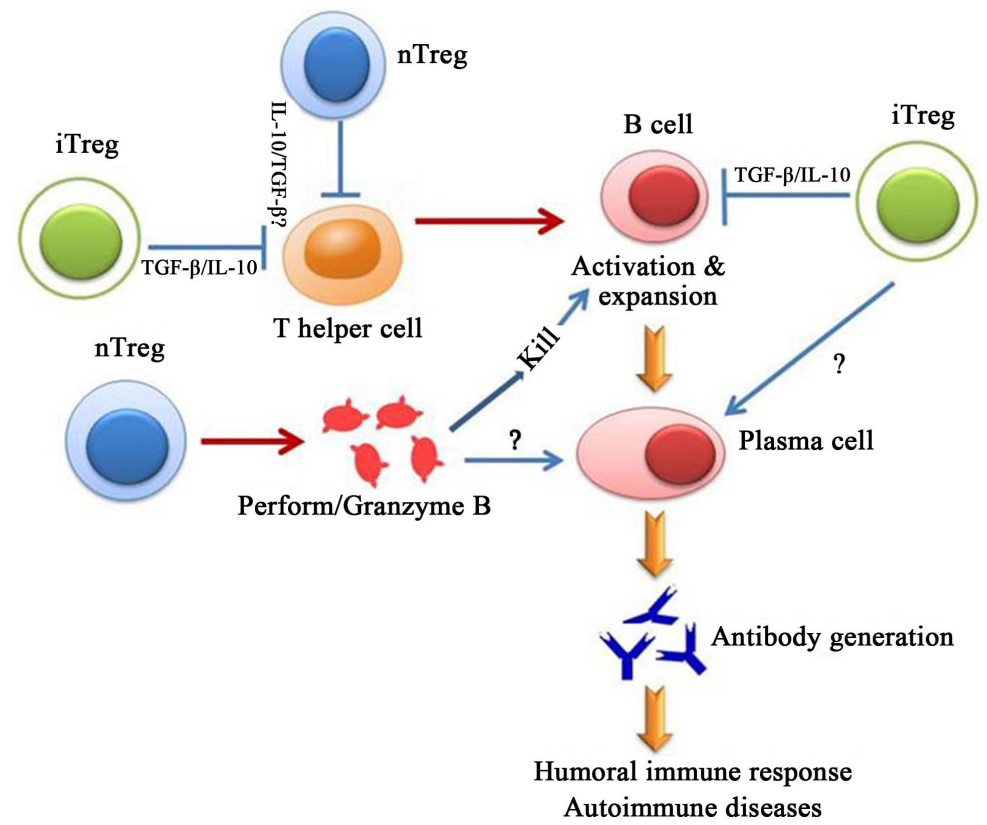

Figure 4. Schematic diagram for the roles of Treg subsets on B cell. Both nTreg and iTreg cells suppress Th cell response that is important for B cell activation. However, both Treg cells also directly suppress B cell response through different mechanisms. While nTreg cells kill B cell through the secretion of Perforin and Granzyme B, iTreg cells suppress B cell response through immune suppressive cytokines including TGF- $\beta$ and IL-10. Both Treg cells may have synergetic role on B cells to regulate the production of antibodies. It is unclear so far whether both Treg cells directly suppress plasma cells. 
marrow chimerism and in the subsequent prevention of acute and chronic allograft rejection (Figure 5 from Lise Pasquet et al.) [65]. They infered this method is expected to allow the establishment of complementary tolerance mechanisms, thus mimicking the complex network of checkpoints and regulatory systems naturally involved in maintenance of self-tolerance (Figure 6 from Lise Pasquet et al.) [65]. Recently emerged importance of regulatory T cell (Treg cell) in allograft tolerance has lead to the concept that the balance between allo-aggressive cytopathic $\mathrm{T}$ cell population and allospecific Treg cell population is crucial to prevent allogeneic graft rejection and go on to graft tolerance [66]-[71]. Research of Yannick D Muller et al. showed that by inhibiting the immunogenicity of effector cells, nTreg could favor a tolerogenic environment that could promote the development of iTreg, contributing to the maintenance of tolerance, the crosstalk between nTreg and alloantigen-presenting DC is important in determining the outcome of the immune tolerance, Pathways of allore-cognition, allograft rejection and mechanisms to induce transplantation tolerance (Figure 7 from Yannick D Muller et al.) [72]. Nina Pilat et al. reported T-regulatory cell treatment prevents chronic rejection of heart allografts in a murine model (Figure 8 from Nina Pilat et al.) [73].

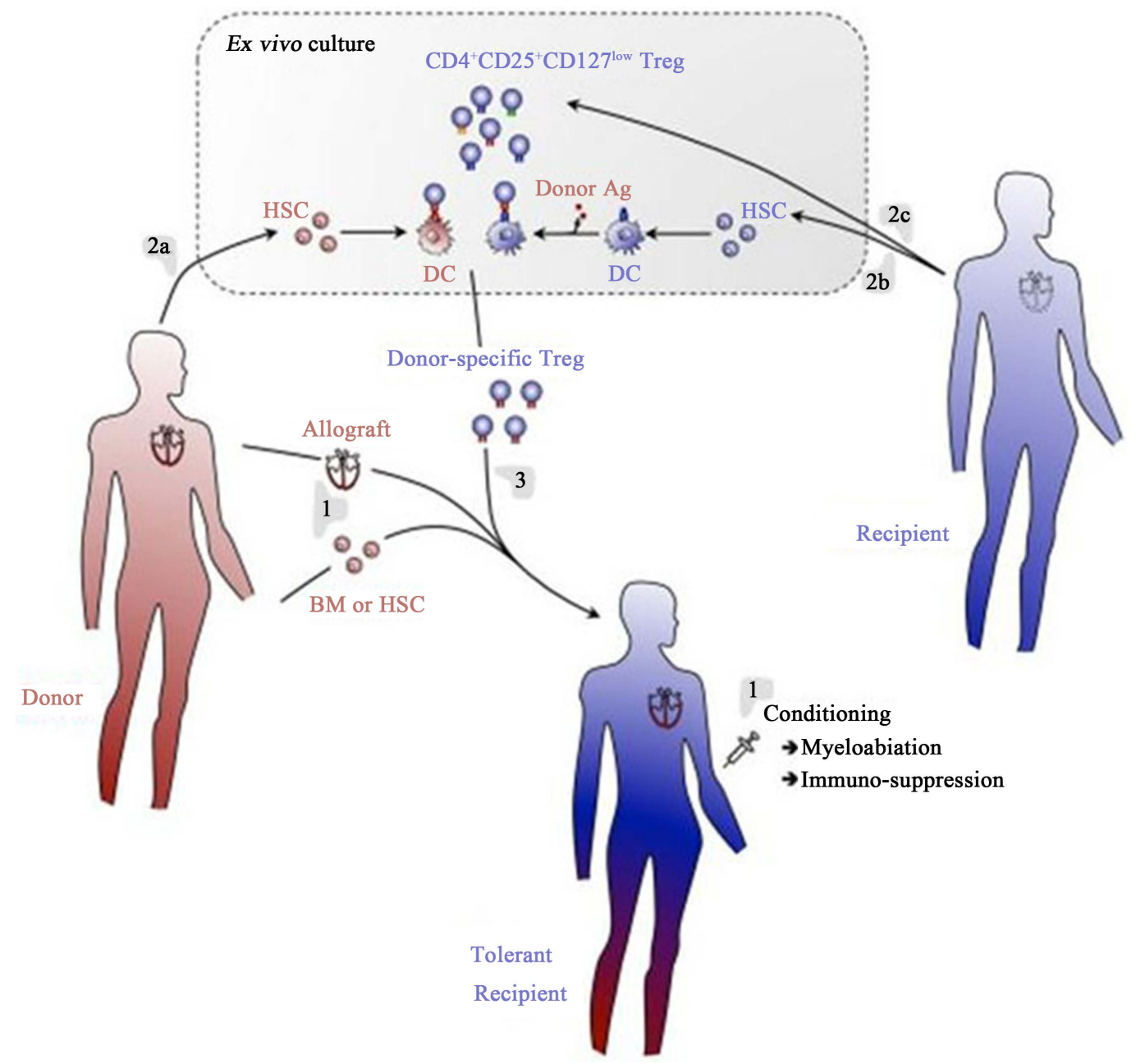

Figure 5. A regulatory T cell/hematopoietic chimerism-based protocol for induction of transplantation tolerance. (1) The allograft (e.g., heart) will be transplanted with concomitant infusion of donor BM or HSC into conditioned hosts. Rejection of the grafts will temporarily be prevented using an immunosuppressive regimen. (2) Donor (a) and host (b) BM will be cultured in vitro under conditions allowing for differentiation of DC. Host DC will be pulsed with donor antigen to assure indirect presentation of these antigens. Thus generated DC will then be co-cultured with host-derived Treg (c), allowing for expansion of Treg specific for directly and indirectly presented donor antigens. (3) Thus generated donor-antigen-specific Treg will then be infused into the host. Immunosuppression may temporarily be continued using drugs that do not affect Treg (e.g., Rapamycin). Using this protocol, full tolerance to donor-tissue will be achieved and chronic rejection effectively prevented. 


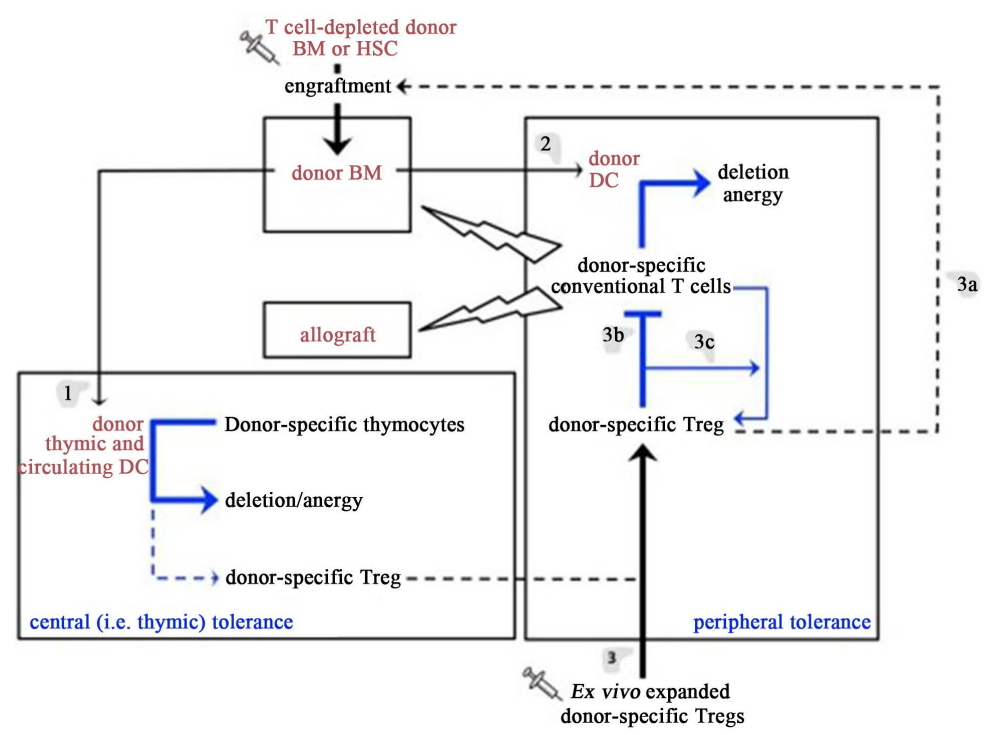

Figure 6. Tolerance mechanisms induced by the proposed regulatory T cell/hematopoietic chimerism-based protocol for induction of transplantation tolerance. (1) Hematopoietic cells (e.g., DC) derived from the grafted BM will colonize the recipient's thymus and induce deletion and anergy (i.e., "recessive tolerance") of developing donorspecific host T lymphocytes. DC may also promote limited differentiation of donor-specific Treg that will contribute to transplantation tolerance. (2) Donor DC will also induce recessive tolerance of mature peripheral donor-specific T lymphocytes. These cells may, to a limited extent, directly induce donor-specific Treg. However, the dominant tolerance (i.e., Treg) induce by hematopoietic chimerism in (1) and (2) appears insufficient to durably prevent most notably chronic allograft rejection. (3) Infusion of donor-specific Treg will aid in engraftment of grafted donor BM/ HSC (a) and inhibit the reactivity of mature peripheral donor-specific T lymphocytes (b), thus favoring graft-acceptance. They will also allow the differentiation of donor-specific conventional T lymphocytes into Treg (c), thus assuring persistence of tolerance and preventing chronic allograft rejection.
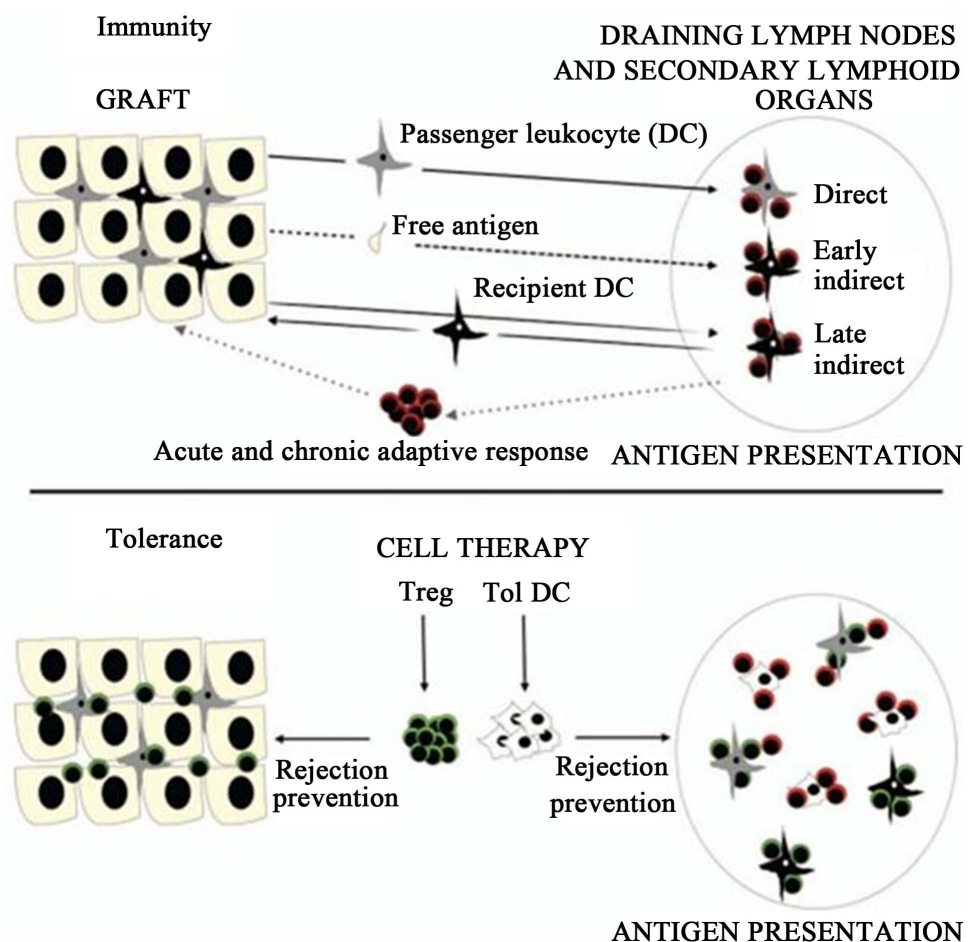

Figure 7. Pathways of Treg cells. Allorecognition, allograft rejection and mechanisms to induce transplantation tolerance. 


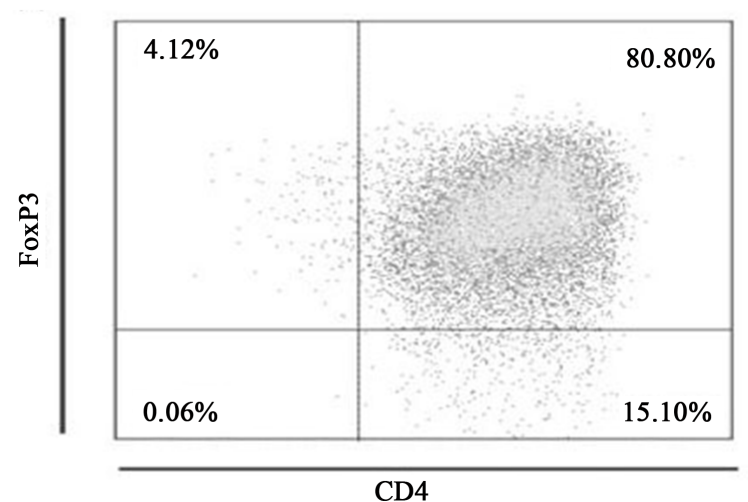

(a)

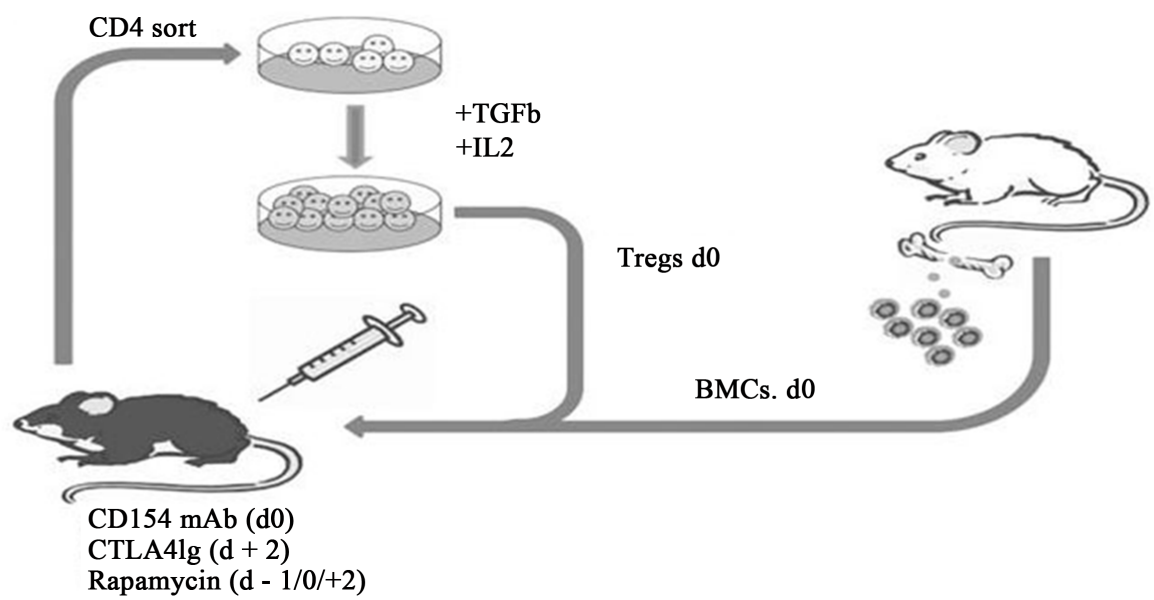

(b)

Figure 8. Treg cells treatment prevent chronic rejection of heart allografts. (a) Representative FACS blot depicting FoxP3 expression among CD4 T cells after in vitro cultivation in the presence of TGF- $\beta$; (b) Schematic drawing of the non-cytotoxic BMT protocol using Tregs. Recipient-type CD4 T cells were separated by magnetic bead sorting and cultivated in the presence of TGF- $\beta$ in vitro. Tregs were infused with fully mismatched allogeneic donor BM under the cover of costimulation blockade and rapamycin.

\section{Tregs and Cancer}

There has been an explosion of literature focusing on the role of regulatory $\mathrm{T}$ (Treg) cells in cancer immunity. It is becoming increasingly clear that Treg cells play an active and significant role in the progression of cancer, and have an important role in suppressing tumor-specific immunity (Figure 9 from Guillaume Darrasse-Jèze et al.) [74]. At the same time, Researchers have identified Treg cell may also play an important role in immune evasion mechanisms employed by cancer [75]-[84] (Figure 10 from Guillaume Darrasse-Jèze et al.) [74]. Tumor-associated Tregs are thought to follow one of two developmental pathways in order to enter the Foxp3 ${ }^{+}$ Treg lineage. First, a developing thymocyte may recognize self antigen presented within the thymus during $\mathrm{T}$ cell maturation (Pathway 1, referred to as natural Tregs ("nTregs"). Alternatively, a conventional CD4 $4^{+} \mathrm{T}$ cell may encounter a tumor-associated (self) or tumor-specific ("neo") antigen in the tumor environment, become activated, and under the influence of an immunosuppressive tumor microenvironment, differentiate into a Foxp3 $^{+}$Treg (Pathway 2, referred to as induced Tregs ("iTregs"). Next, within the tumor environment, Tregs may respond to context-dependent inflammatory signals (e.g. Th1, Th2, or Th17 inflammation), the tissue or organ type (e.g. colon, breast, or prostate) and even the immediate proximal microenvironment (e.g. stroma, tumor bed, or lymphoid cluster). From these environmental cues, Tregs are capable of mediating distinct functions, which may include promotion of angiogenesis or metastasis, regulation of inflammation, and suppression of anti-tumor adaptive immune responses (Figure 11 from Peter A. Savage et al.) [85]. Tumors may differentiate, expand, recruit, and activate Treg (tumor Treg) cells via multiple mechanisms and potently abrogate antitumor 
(a) IMMUNOSUPPRESSIVE CYTOKINES

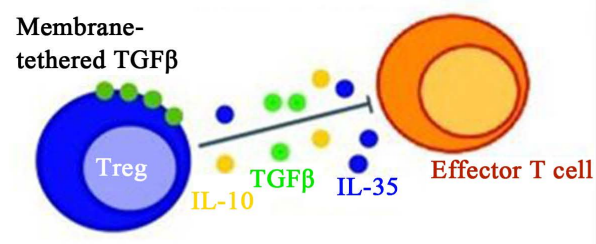

(c)METABOLIC DISRUPTION BY IL-2 DEPRIVATION

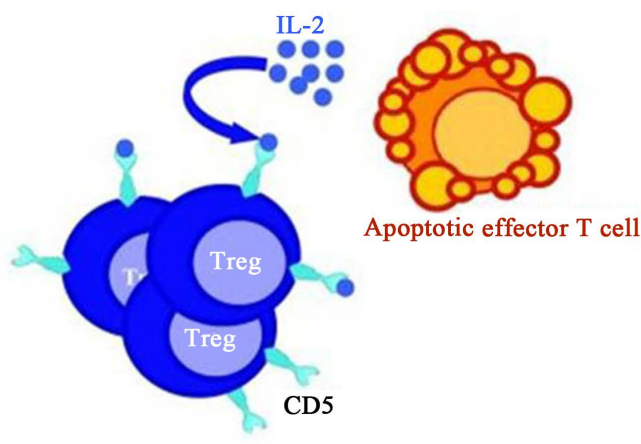

(b) CYOLYSIS

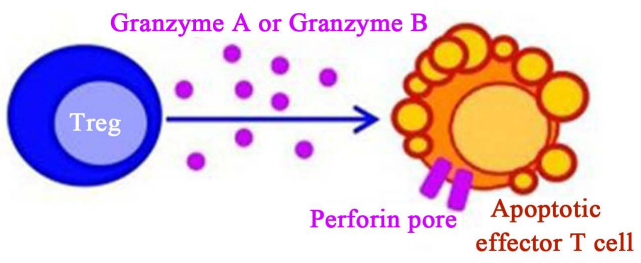

(d) INHIBITION OF DC MATURATION AND FUNCTION

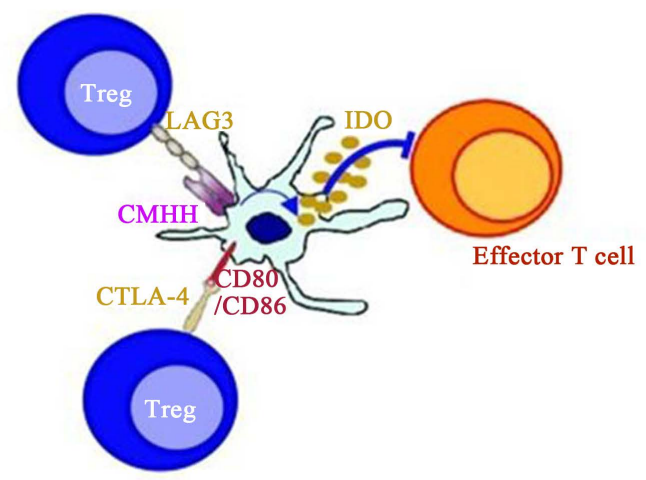

Figure 9. Mechanisms of Treg cells inhibition for cancer. (a) Secretion of immunosuppressive cytokines (IL-10, IL-35 and TGF $\beta$ ) inhibiting effector T cells; (b) Cytolysis of effector T cells by production of Granzyme A and/or B; (c) Metabolic disruption of effector T cells by IL-2 deprivation. IL-2 is captured by CD25 expressed by Treg; (d) Inhibition of DC maturation by contact-dependent mechanisms (CTLA-4, CD80-CD86 interaction, Lag3/ CMHII interaction) and effector function by IDO secretion.

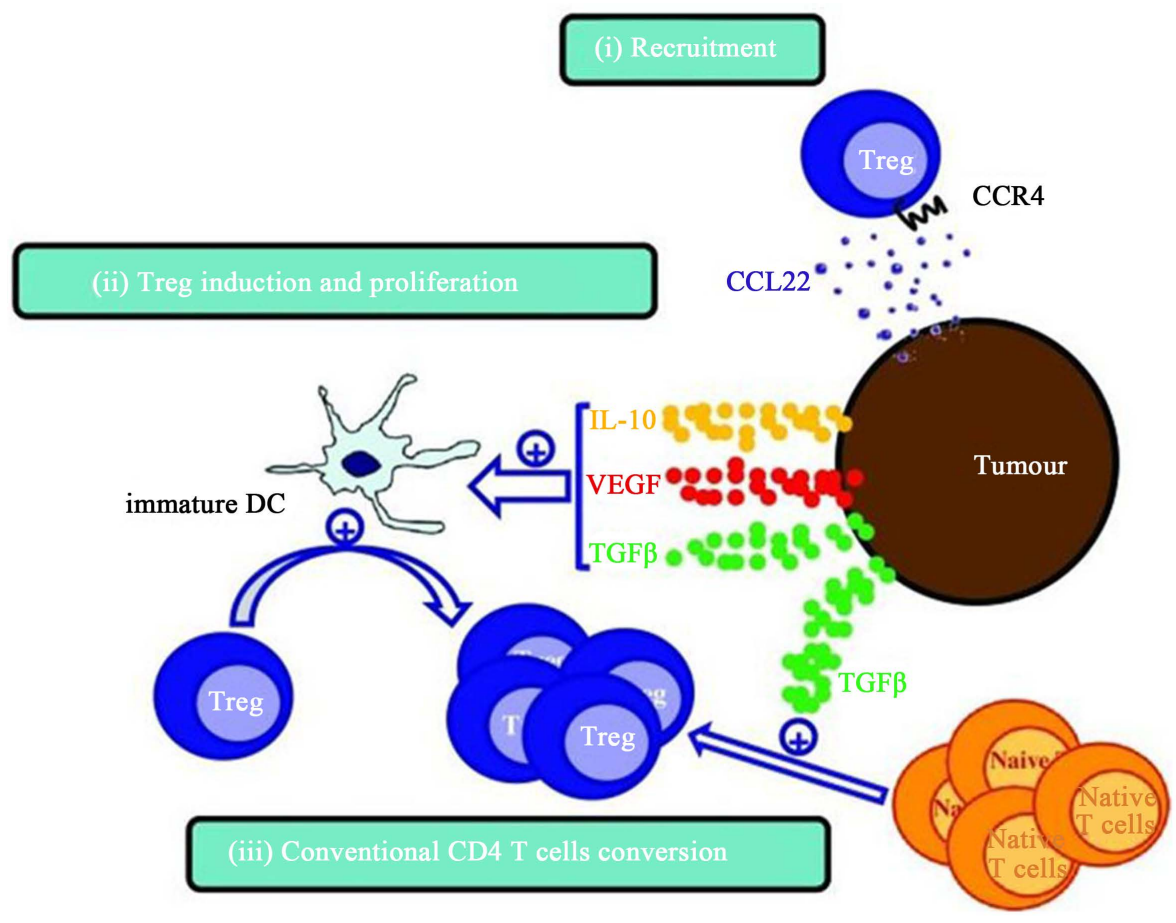

Figure 10. Recruitment, proliferation and induction of Treg in the tumor microenvironment. (i) Recruitment of CCR $4^{+}$activated Treg by a CCL22 gradient produced by the tumor. (ii) Tumor expression of VEGF, IL-10 or TGF $\beta$ blocks DC maturation responsible for Treg induction and proliferation. (iii) TGF $\beta$ secreted by the tumor converts conventional $\mathrm{CD} 4^{+} \mathrm{T}$ cells into regulatory $\mathrm{T}$ cells. 


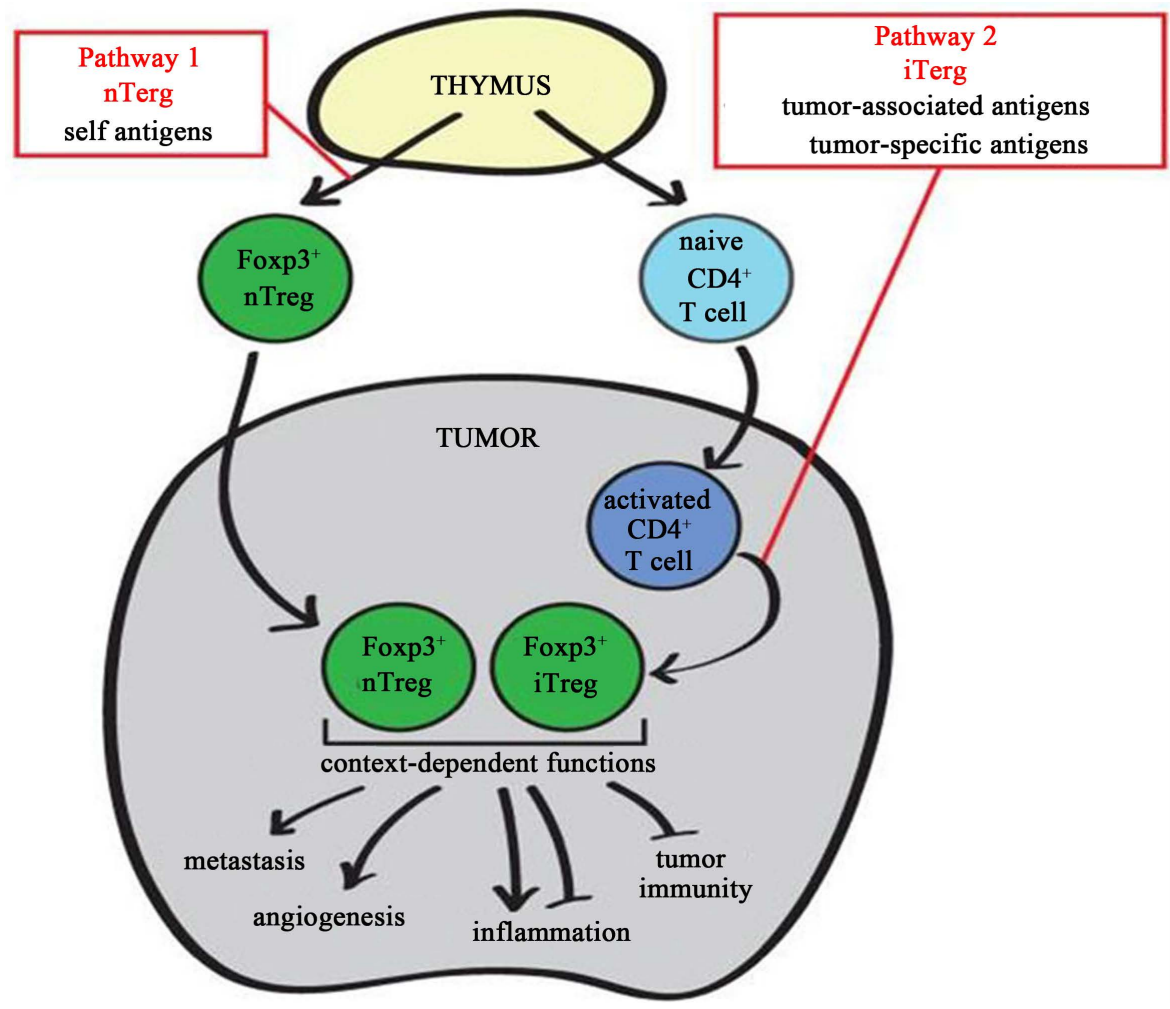

Figure 11. Conceptual model describing the biology of tumor-associated Tregs. Pathway 1: a developing thymocyte may recognize self antigen presented within the thymus during T cell maturation. Pathway 2: a conventional $\mathrm{CD}^{+}{ }^{+} \mathrm{T}$ cell may encounter a tumor-associated (self) or tumor-specific ("neo") antigen in the tumor environment, become activated, and under the influence of an immunosuppressive tumor microenvironment, differentiate into a Foxp $3^{+}$Treg.

immunity [86]-[93]. Figure 12 shows a schematic diagram of tumor-mediated generation of Treg cells in tumor microenvironment. Guillaume Darrasse-Jèze and Katrina Podsypanina reported activated memory Tregs in the Early Immune Response to Cancer (Figure 13 from Guillaume Darrasse-Jèze et al.) [75]. and immune tolerance vs. immune rejection decision process (Figure 14 from Guillaume Darrasse-Jèze et al.) [75].

\section{Prospect of Treg Cells Research}

Treg cells play an indispensable role in the immune system as they are involved in the prevention of autoimmune diseases, allergies, infection-induced organ pathology, transplant rejection as well as graft versus host disease (GvHD) by suppression of effector T cells and other immune cells. As we know from above Treg cells can induce immune tolerance to decrease the risk of acute and chronic graft rejection after solid organ transplantation and improve transplanted organ survival [94]-[96]. On the other hand, they are also contributed to the progress of many tumours. As cancer cells express both self- and tumour-associated antigens, Treg cells are the key to dampening effector cell responses, and therefore represent one of the main obstacles to effective anti-tumour responses. How to deal with the Treg cells in the balance between transplantation tolerance and cancer (Figure 15 from Eefje $M$ et al.) [97]? The successful application of Treg therapy in allograft and at the same time prevent tumor formation, there are multiple issues addressed: 1) the efficacy of Treg and the number of cells necessary to obtain a therapeutic effect [85] [98]; 2) the Ag specificity necessary for safe and effective control of rejection; 3) the stability of the suppressive phenotype of adoptively-transferred Treg [82] [99] [100]; 4) the Treg migratory pattern that guarantees the strongest regulatory function; 5) the conditions permissive to regulation of the memory response; 6 ) the ability of Treg to control the xeno-reactive response; 7) the impact of lymphocyte depletion/concomitant immunosuppressive therapy on Treg function. So Treg cells are subject to intense investigations [88] [101]; 8) strategies to target cancer will rely on combining control of Treg cells 


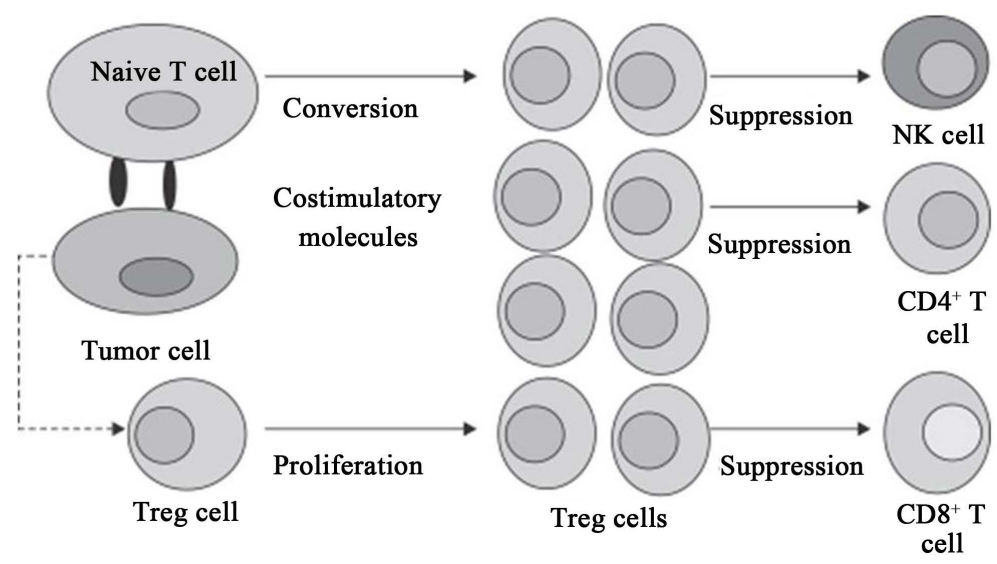

Figure 12. Tumor-mediated generation of regulatory T (Treg) cells and the effect on the tumor microenvironment. Tumor cells induce the generation of Treg cells through both cell contact-dependent and cell contact-independent mechanisms. Soluble protein such as TGF $\beta$ produced by tumor cells promote the proliferation of Treg cells and induce the conversion of naive $\mathrm{CD} 4^{+} \mathrm{CD} 25^{-} \mathrm{T}$ cells into Treg cells. Tumor cells also express costimulatory molecules such as CD80/CD86 or CD70 and interact with naive T cells to convert these naive T cells into Treg cells. The increased numbers of Treg cells inhibit the NK cells, CD4 ${ }^{+} \mathrm{T}$ cells, CD8 ${ }^{+} \mathrm{T}$ cells and the other cells and contribute to the progression of tumors.

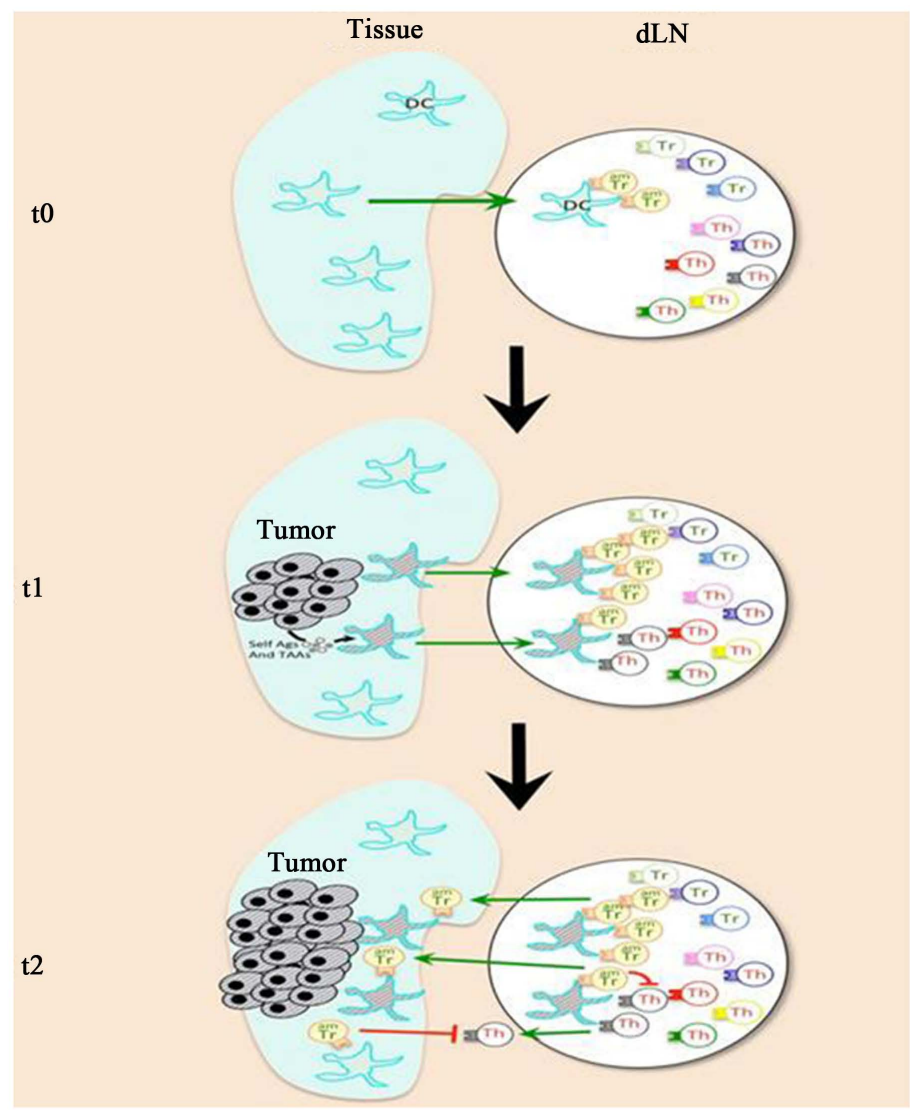

Fiigre 13. Early events during cancer emergence lead to immune tolerance against tumor. Activated memory Tregs (AmTregs or amTr, beige lymphocytes) are the first to be stimulated by the presence of the tumor (gray round-shaped cells) via recognition of self-Ag presented by dendritic cells (DCs, star-shaped cells) coming from the tumor site (t1). AmTreg will then proliferate faster than TAA-specific Teffs (Th, gray lymphocytes) that are naïve (or have already been suppressed at the steady state). AmTreg will then inhibit either Teff activation, proliferation, migration, and function either/or DCs presentation and costimulation (t2). 

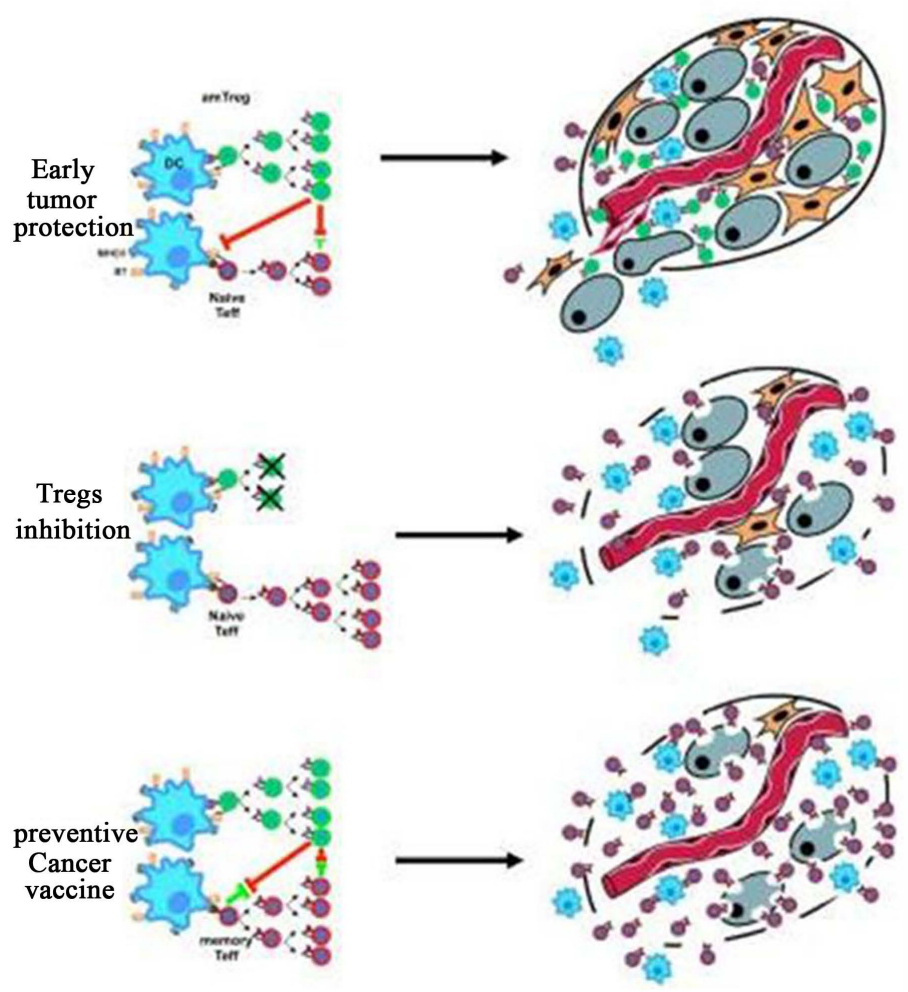

Figure 14. Immune tolerance vs. Immune rejection decision process. Activation kinetics and memory status of Tregs (green) and Teffs (red) in the tumor-draining lymph nodes (dLNs, left) after stimulation by dendritic cells (DC, blue) result in the infiltration of the tumor by different cell subsets with different speed and different tumor fate (right, with tumor cells in gray).

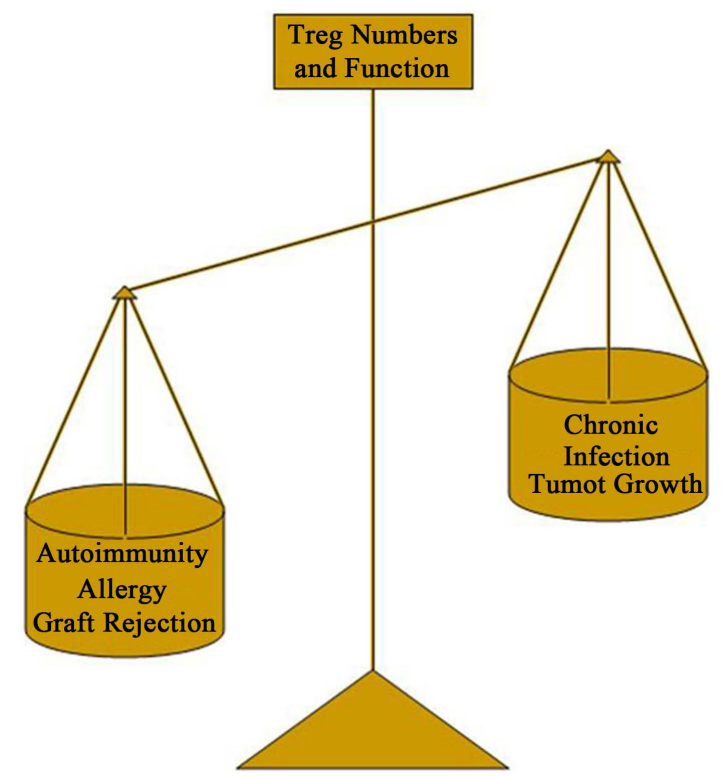

Figure 15. Reduction or increase in Treg cell numbers/activity is implicated in various pathologies. Reduction in Treg cell numbers or activity results in the development of autoimmunity, allergy and graft rejection. Increases in Treg cell numbers or aberrant function may cause susceptibility to chronic infection and predispose to tumor development. 
function and Teff/Treg ratios; 9) use the target of specific Treg subsets to prevent tumor [102] [103]. In a word, the research of Treg cells is an interesting subject and worth to intensively investigate.

\section{Acknowledgements}

This report was supported by Sanya City Special Fund for Scientist Development, project number YW1205.

\section{References}

[1] Hsieh, C.S., Lee, H.M. and Lio, C.W. (2012) Selection of Regulatory T Cells in the Thymus. Nature Reviews Immunology, 12, 157-167. http://dx.doi.org/10.1038/nri3155

[2] Sakaguchi, S. (2011) Regulatory T Cells: History and Perspective. Methods in Molecular Biology, 707, 3-17. http://dx.doi.org/10.1007/978-1-61737-979-6_1

[3] Hippen, K.L., Merkel, S.C., Schirm, D.K., et al. (2011) Generation and Large-Scale Expansion of Human Inducible Regulatory T Cells That Suppress Graft-versus-Host Disease. American Journal of Transplantation, 11, 1148-1157. http://dx.doi.org/10.1111/j.1600-6143.2011.03558.x

[4] Khan, M.A. and Nicolls, M.R. (2013) Complement-Mediated Microvascular Injury Leads to Chronic Rejection. Advances in Experimental Medicine and Biology, 734, 233-246. http://dx.doi.org/10.1007/978-1-4614-4118-2_16

[5] Griesemer, A.D., Sorenson, E.C. and Hardy, M.A. (2010) The Role of the Thymus in Tolerance. Transplantation, 90, 465-474. http://dx.doi.org/10.1097/TP.0b013e3181e7e54f

[6] Hori, S., Nomura, T. and Sakaguchi, S. (2003) Control of Regulatory T Cell Development by the Transcription Factor Foxp3. Science, 299, 1057-1061. http://dx.doi.org/10.1126/science.1079490

[7] Issa, F. and Wood, K.J. (2010) CD4 ${ }^{+}$Regulatory T Cells in Solid Organ Transplantation. Current Opinion in Organ Transplantation, 15, 757-764. http://dx.doi.org/10.1097/MOT.0b013e32834017ae

[8] Schmetterer, K.G., Neunkirchner, A. and Pickl, W.F. (2012) Naturally Occurring Regulatory T Cells: Markers, Mechanisms, and Manipulation. The FASEB Journal, 26, 2253-2276. http://dx.doi.org/10.1096/fj.11-193672

[9] Baecher-Allan, C., Wolf, E. and Hafler, D.A. (2005) Functional Analysis of Highly Defined, FACS-Isolated Populations of Human Regulatory CD4 ${ }^{+} \mathrm{CD} 25^{+}$T Cells. Clinical Immunology, 115, 10-18. http://dx.doi.org/10.1016/j.clim.2005.02.018

[10] Salomon, B. and Bluestone, J.A. (2001) Complexities of CD28/B7: CTLA-4 Costimulatory Pathways in Autoimmunity and Transplantation. Annual Review of Immunology, 19, 225-252. http://dx.doi.org/10.1146/annurev.immunol.19.1.225

[11] Soligo, M., Camperio, C., Caristi, S., et al. (2011) CD28 Costimulation Regulates FOXP3 in a RelA/NF- $\kappa$ B-Dependent Mechanism. European Journal of Immunology, 41, 503-513. http://dx.doi.org/10.1002/eji.201040712

[12] Josefowicz, S.Z., Lu, L.F. and Rudensky, A.Y. (2012) Regulatory T Cells: Mechanisms of Differentiation and Function. Annual Review of Immunology, 30, 531-564. http://dx.doi.org/10.1146/annurev.immunol.25.022106.141623

[13] Josefowicz, S.Z., Niec, R.E., Kim, H.Y., et al (2012). Extrathymically Generated Regulatory T Cells Control Mucosal $\mathrm{T}_{\mathrm{H}} 2$ Inflammation. Nature, 482, 395-399. http://dx.doi.org/10.1038/nature10772

[14] Samstein, R.M., Arvey, A., Josefowicz, S.Z., et al. (2012) Foxp3 Exploits a Pre-Existent Enhancer Landscape for Regulatory T Cell Lineage Specification. Cell, 151, 153-166. http://dx.doi.org/10.1016/j.cell.2012.06.053

[15] Greaves, P., Clear, A., Coutinho, R., et al. (2013) Expression of FOXP3, CD68, and CD20 at Diagnosis in the Microenvironment of Classical Hodgkin Lymphoma Is Predictive of Outcome. Journal of Clinical Oncology, 31, $256-262$. http://dx.doi.org/10.1200/JCO.2011.39.9881

[16] Bilate, A.M. and Lafaille, J.J. (2012) Induced CD4 ${ }^{+}$Foxp $^{+}$Regulatory T Cells in Immune Tolerance. Annual Review of Immunology, 30, 733-758. http://dx.doi.org/10.1146/annurev-immunol-020711-075043

[17] Nankivell, B.J. and Alexander, S.I. (2010) Rejection of the Kidney Allograft. The New England Journal of Medicine, 363, 1451-1462. http://dx.doi.org/10.1056/NEJMra0902927

[18] Bohmig, G.A., Wahrmann, M. and Saemann, M.D. (2010) Detecting Adaptive Immunity: Applications in Transplantation Monitoring. Molecular Diagnosis \& Therapy, 14, 1-11. http://dx.doi.org/10.1007/BF03256348

[19] Sandrin, M.S. (2009) Transplantation Immunobiology: Two Important Themes. Immunology \& Cell Biology, 87, 194. http://dx.doi.org/10.1038/icb.2009.6

[20] Fandrich, F. (2011) Tolerance in Clinical Transplantation: Progress, Challenge or Just a Dream? Langenbeck's Archives of Surgery, 396, 475-487. http://dx.doi.org/10.1007/s00423-011-0757-z 
[21] Hernandez-Fuentes, M.P. and Lechler, R.I. (2010) A “Biomarker Signature” for Tolerance in Transplantation. Nature Reviews Nephrology, 6, 606-613. http://dx.doi.org/10.1038/nrneph.2010.112

[22] Moore, R., Ravindran, V. and Baboolal, K. (2006) The Burden of New-Onset Diabetes Mellitus after Transplantation. Clinical Transplantation, 20, 755-761. http://dx.doi.org/10.1111/j.1399-0012.2006.00565.X

[23] Wadei, H.M. and Textor, S.C. (2010) Hypertension in the Kidney Transplant Recipient. Transplantation Reviews (Orlando), 24, 105-120. http://dx.doi.org/10.1016/j.trre.2010.02.001

[24] Onishi, H., Morisaki, T. and Katano, M. (2012) Immunotherapy Approaches Targeting Regulatory T-Cells. Anticancer Research, 32, 997-1003.

[25] Bluestone, J.A., Liu, W., Yabu, J.M., et al. (2008) The Effect of Costimulatory and Interleukin 2 Receptor Blockade on Regulatory T Cells in Renal Transplantation. American Journal of Transplantation, 8, 2086-2096. http://dx.doi.org/10.1111/j.1600-6143.2008.02377.x

[26] de Rezende, L.C., Silva, I.V., Rangel, L.B. and Guimaraes, M.C. (2010) Regulatory T Cell as a Target for Cancer Therapy. Archivum Immunologiae et Therapia Experimentalis (Warsz), 58, 179-190. http://dx.doi.org/10.1007/s00005-010-0075-0

[27] Kawai, M., Kitade, H., Mathieu, C., et al. (2005) Inhibitory and Stimulatory Effects of Cyclosporine A on the Development of Regulatory T Cells in Vivo. Transplantation, 79, 1073-1077. http://dx.doi.org/10.1097/01.TP.0000153505.73700.32

[28] Demirkiran, A., Sewgobind, V.D., van der Weijde, J., et al. (2009) Conversion from Calcineurin Inhibitor to Mycophenolate Mofetil-Based Immunosuppression Changes the Frequency and Phenotype of $\mathrm{CD}^{+} \mathrm{FOXP}^{+}$Regulatory $\mathrm{T}$ Cells. Transplantation, 87, 1062-1068. http://dx.doi.org/10.1097/tp.0b013e31819d2032

[29] Zhang, Z.X., Yang, L., Young, K.J., DuTemple, B. and Zhang, L. (2000) Identification of a Previously Unknown Antigen-Specific Regulatory T Cell and Its Mechanism of Suppression. Nature Medicine, 6, 782-789. http://dx.doi.org/10.1038/77513

[30] Monteiro, M., Almeida, C.F., Caridade, M., et al. (2010) Identification of Regulatory Foxp3 ${ }^{+}$Invariant NKT Cells Induced by TGF-Beta. The Journal of Immunology, 185, 2157-2163. http://dx.doi.org/10.4049/jimmunol.1000359

[31] Curiel, T.J., Coukos, G., Zou, L., et al. (2004) Specific Recruitment of Regulatory T Cells in Ovarian Carcinoma Fosters Immune Privilege and Predicts Reduced Survival. Nature Medicine, 10, 942-949. http://dx.doi.org/10.1038/nm1093

[32] Miyara, M. and Sakaguchi, S. (2011) Human FoxP3 ${ }^{+} \mathrm{CD} 4^{+}$Regulatory T Cells: Their Knowns and Unknowns. Immunology and Cell Biology, 89, 346-351. http://dx.doi.org/10.1038/icb.2010.137

[33] Collison, L.W., Workman, C.J., Kuo, T.T., et al. (2007) The Inhibitory Cytokine IL-35 Contributes to Regulatory T-Cell Function. Nature, 450, 566-569. http://dx.doi.org/10.1038/nature06306

[34] Fassbender, M., Gerlitzki, B., Ullrich, N., et al. (2010) Cyclic Adenosine Monophosphate and IL-10 Coordinately Contribute to nTreg Cell-Mediated Suppression of Dendritic Cell Activation. Cellular Immunology, 265, 91-96. http://dx.doi.org/10.1016/j.cellimm.2010.07.007

[35] Tsang, J.Y., Tanriver, Y., Jiang, S., et al. (2009) Indefinite Mouse Heart Allograft Survival in Recipient Treated with $\mathrm{CD} 4{ }^{+} \mathrm{CD} 25^{+}$Regulatory T Cells with Indirect Allospecificity and Short Term Immunosuppression. Transplant Immunology, 21, 203-209. http://dx.doi.org/10.1016/j.trim.2009.05.003

[36] Golshayan, D., Jiang, S., Tsang, J., Garin, M.I., Mottet, C. and Lechler, R.I. (2007) In Vitro-Expanded Donor Alloantigen-Specific CD $4^{+} \mathrm{CD} 25^{+}$Regulatory T Cells Promote Experimental Transplantation Tolerance. Blood, 109, 827-835. http://dx.doi.org/10.1182/blood-2006-05-025460

[37] Joffre, O., Santolaria, T., Calise, D., et al. (2008) Prevention of Acute and Chronic Allograft Rejection with CD4 CD25 ${ }^{+}$Foxp3 $^{+}$Regulatory T Lymphocytes. Nature Medicine, 14, 88-92. http://dx.doi.org/10.1038/nm1688

[38] Cao, T., Soto, A., Zhou, W., et al. (2009) Ex Vivo Expanded Human CD4 ${ }^{+}$CD25 ${ }^{+}$Foxp3 ${ }^{+}$Regulatory T Cells Prevent Lethal Xenogenic Graft versus Host Disease (GVHD). Cellular Immunology, 258, 65-71. http://dx.doi.org/10.1016/j.cellimm.2009.03.013

[39] Shalev, I., Schmelzle, M., Robson, S.C. and Levy, G. (2011) Making Sense of Regulatory T Cell Suppressive Function. Seminars in Immunology, 23, 282-292. http://dx.doi.org/10.1016/j.smim.2011.04.003

[40] Nadig, S.N., Wieckiewicz, J., Wu, D.C., et al. (2010) In Vivo Prevention of Transplant Arteriosclerosis by ex VivoExpanded Human Regulatory T Cells. Nature Medicine, 16, 809-813. http://dx.doi.org/10.1038/nm.2154

[41] Issa, F., Hester, J., Goto, R., Nadig, S.N., Goodacre, T.E. and Wood, K. (2010) Ex Vivo-Expanded Human Regulatory T Cells Prevent the Rejection of Skin Allografts in a Humanized Mouse Model. Transplantation, 90, 1321-1327. http://dx.doi.org/10.1097/TP.0b013e3181ff8772

[42] Tran, D.Q., Andersson, J., Hardwick, D., Bebris, L., Illei, G.G. and Shevach, E.M. (2009) Selective Expression of La- 
tency-Associated Peptide (LAP) and IL-1 Receptor Type I/II (CD121a/CD121b) on Activated Human FOXP3 ${ }^{+}$Regulatory T Cells Allows for Their Purification from Expansion Cultures. Blood, 113, 5125-5133. http://dx.doi.org/10.1182/blood-2009-01-199950

[43] Ukena, S.N., Hopting, M., Velaga, S., et al. (2011) Isolation Strategies of Regulatory T Cells for Clinical Trials: Phenotype, Function, Stability, and Expansion Capacity. Experimental Hematology, 39, 1152-1160. http://dx.doi.org/10.1016/j.exphem.2011.08.010

[44] Marek, N., Bieniaszewska, M., Krzystyniak, A., et al. (2011) The Time Is Crucial for ex Vivo Expansion of T Regulatory Cells for Therapy. Cell Transplantation, 20, 1747-1758. http://dx.doi.org/10.3727/096368911X566217

[45] Tresoldi, E., Dell’Albani, I., Stabilini, A., et al. (2011) Stability of Human Rapamycin-Expanded CD4 ${ }^{+}$CD25 ${ }^{+}$T Regulatory Cells. Haematologica, 96, 1357-1365. http://dx.doi.org/10.3324/haematol.2011.041483

[46] Gurkan, S., Luan, Y., Dhillon, N., et al. (2010) Immune Reconstitution Following Rabbit Antithymocyte Globulin. American Journal of Transplantation, 10, 2132-2141. http://dx.doi.org/10.1111/j.1600-6143.2010.03210.x

[47] Sojka, D.K., Huang, Y.-H. and Fowell, D.J. (2008) Mechanisms of Regulatory T-Cell Suppression-A Diverse Arsenal for a Moving Target. Immunology, 124, 13-22. http://dx.doi.org/10.1111/j.1365-2567.2008.02813.X

[48] Lim, H.W., Hillsamer, P., Banham, A.H. and Kim, C.H. (2005) Cutting Edge: Direct Suppression of B Cells by CD4 CD25 ${ }^{+}$Regulatory T Cells. The Journal of Immunology, 175, 4180-4183. http://dx.doi.org/10.4049/jimmunol.175.7.4180

[49] Fan, Z., Spencer, J.A., Lu, Y., et al. (2010) In Vivo Tracking of “Color-Coded” Effector, Natural and Induced Regulatory T Cells in the Allograft Response. Nature Medicine, 16, 718-722. http://dx.doi.org/10.1038/nm.2155

[50] Tsang, J.Y., Ratnasothy, K., Li, D., et al. (2011) The Potency of Allospecific Tregs Cells Appears to Correlate with T Cell Receptor Functional Avidity. American Journal of Transplantation, 11, 1610-1620. http://dx.doi.org/10.1111/j.1600-6143.2011.03650.x

[51] Feng, G., Nadig, S.N., Backdahl, L., et al. (2011) Functional Regulatory T Cells Produced by Inhibiting Cyclic Nucleotide Phosphodiesterase Type 3 Prevent Allograft Rejection. Science Translational Medicine, 3, 83ra40. http://dx.doi.org/10.1126/scitranslmed.3002099

[52] Ding, Y., Xu, J. and Bromberg, J.S. (2012) Regulatory T Cell Migration during an Immune Response. Trends in Immunology, 33, 174-180. http://dx.doi.org/10.1016/j.it.2012.01.002

[53] Duhen, T., Duhen, R., Lanzavecchia, A., Sallusto, F. and Campbell, D.J. (2012) Functionally Distinct Subsets of Human FOXP3 ${ }^{+}$Treg Cells That Phenotypically Mirror Effector Th Cells. Blood, 119, 4430-4440. http://dx.doi.org/10.1182/blood-2011-11-392324

[54] Sagoo, P., Perucha, E., Sawitzki, B., et al. (2010) Development of a Cross-Platform Biomarker Signature to Detect Renal Transplant Tolerance in Humans. Journal of Clinical Investigation, 120, 1848-1861. http://dx.doi.org/10.1172/JCI39922

[55] Di Ianni, M., Falzetti, F., Carotti, A., et al. (2011) Tregs Prevent GVHD and Promote Immune Reconstitution in HLAHaploidentical Transplantation. Blood, 117, 3921-3928. http://dx.doi.org/10.1182/blood-2010-10-311894

[56] Kimura, A. and Kishimoto, T. (2010) IL-6: Regulator of Treg/Th17 Balance. European Journal of Immunology, 40, 1830-1835. http://dx.doi.org/10.1002/eji.201040391

[57] Fujimoto, M., Nakano, M., Terabe, F., et al. (2011) The Influence of Excessive IL-6 Production in Vivo on the Development and Function of Foxp3 ${ }^{+}$Regulatory T Cells. The Journal of Immunology, 186, 32-40. http://dx.doi.org/10.4049/jimmunol.0903314

[58] Kim, J., Sonawane, S., Lee, M.K., et al. (2010) Blockade of GITR-GITRL Interaction Maintains Regulatory T Cell Function to Prolong Allograft Survival. European Journal of Immunology, 40, 1369-1374. http://dx.doi.org/10.1002/eji.200940046

[59] Quigley, M.F. (2010) Convergent Recombination Shapes the Clonotypic Landscape of the Naive T-Cell Repertoire. Proceedings of the National Academy of Sciences of the United States of America, 107, 19414-19419. http://dx.doi.org/10.1073/pnas.1010586107

[60] Thomas, P.G., Handel, A., Doherty, P.C., et al. (2013) Ecological Analysis of Antigen-Specific CTL Repertoires Defines the Relationship between Naive and Immune T-Cell Populations. Proceedings of the National Academy of Sciences of the United States of America, 110, 1839-1844. http://dx.doi.org/10.1073/pnas.1222149110

[61] Guillonneau, C., Picarda, E. and Anegon, I. (2010) CD8 ${ }^{+}$Regulatory T Cells in Solid Organ Transplantation. Current Opinion in Organ Transplantation, 15, 751-756. http://dx.doi.org/10.1097/MOT.0b013e32834016d1

[62] Li, X.L., et al. (2010) Mechanism and Localization of CD8 Regulatory T Cells in a Heart Transplant Model of Tolerance. The Journal of Immunology, 185, 823-833. http://dx.doi.org/10.4049/jimmunol.1000120

[63] Picarda, E., Anegon, I. and Guillonneau, C. (2011) T-Cell Receptor Specificity of CD8 ${ }^{+}$Tregs in Allotransplantation. 
Immunotherapy, 3, 35-37. http://dx.doi.org/10.2217/imt.11.37

[64] Sagoo, P., Ali, N., Garg, G., et al. (2011) Human Regulatory T Cells with Alloantigen Specificity Are More Potent Inhibitors of Alloimmune Skin Graft Damage than Polyclonal Regulatory T Cells. Science Translational Medicine, 3 , 83-92. http://dx.doi.org/10.1126/scitranslmed.3002076

[65] Pasquet, L., Joffre, O., Santolaria, T., et al. (2011) Hematopoietic Chimerism and Transplantation Tolerance: A Role for Regulatory T Cells. Frontiers in Immunology, 2, 80. http://dx.doi.org/10.3389/fimmu.2011.00080

[66] Ohkura, N. and Sakaguchi, S. (2010) Regulatory T Cells: Roles of T Cell Receptor for Their Development and Function. Seminars in Immunopathology, 32, 95-106. http://dx.doi.org/10.1007/s00281-010-0200-5

[67] Fohse, L. (2011) High TCR Diversity Ensures Optimal Function and Homeostasis of Foxp3 ${ }^{+}$Regulatory T Cells. European Journal of Immunology, 41, 3101-3113. http://dx.doi.org/10.1002/eji.201141986

[68] Wood, K.J., Bushell, A. and Hester, J. (2012) Regulatory Immune Cells in Transplantation. Nature Reviews Immunology, 12, 417-430. http://dx.doi.org/10.1038/nri3227

[69] Liu, Y.C. (2012) The Energetic Basis Underpinning T-Cell Receptor Recognition of a Super-Bulged Peptide Bound to a Major Histocompatibility Complex Class I Molecule. The Journal of Biological Chemistry, 287, 12267-12276. http://dx.doi.org/10.1074/jbc.M112.344689

[70] Ekeruche-Makinde, J. (2013) Peptide Length Determines the Outcome of TCR/Peptide-MHCI Engagement. Blood, 121, 1112-1123. http://dx.doi.org/10.1182/blood-2012-06-437202

[71] Leavenworth, J.W., Tang, X., Kim, H.J., et al. (2013) Amelioration of Arthritis through Mobilization of Peptide-Specific CD8 ${ }^{+}$Regulatory T Cells. Journal of Clinical Investigation, 123, 1382-1389. http://dx.doi.org/10.1172/JCI66938

[72] Muller, Y.D., Seebach, J.D., Bühler, L.H., et al. (2011) Transplantation Tolerance: Clinical Potential of Regulatory T Cells. Self/Nonself, 2, 26-34. http://dx.doi.org/10.4161/self.2.1.15422

[73] Pilat, N., Farkas, A.M., et al. (2014) T-Regulatory Cell Treatment Prevents Chronic Rejection of Heart Allografts in a Murine Mixed Chimerism Model. The Journal of Heart and Lung Transplantation, 33, 429-437. http://dx.doi.org/10.1016/j.healun.2013.11.004

[74] Darrasse-Jèze, G. and Podsypanina, K. (2013) How Numbers, Nature, and Immune Status of Foxp3 ${ }^{+}$Regulatory TCells Shape the Early Immunological Events in Tumor Development. Frontiers in Immunology, 4, 292. http://dx.doi.org/10.3389/fimmu.2013.00292

[75] Hollenbeak, C.S., Todd, M.M., Billingsley, E.M., et al. (2005) Increased Incidence of Melanoma in Renal Transplantation Recipients. Cancer, 104, 1962-1710. http://dx.doi.org/10.1002/cncr.21404

[76] Zhang, L., Conejo-Garcia, J.R., Katsaros, D., et al. (2003) Intratumoral T Cells, Recurrence, and Survival in Epithelial Ovarian Cancer. The New England Journal of Medicine, 348, 203-213. http://dx.doi.org/10.1056/NEJMoa020177

[77] Liyanage, U.K., Moore, T.T., Joo, H.G., et al. (2002) Prevalence of Regulatory T Cells Is Increased in Peripheral Blood and Tumor Microenvironment of Patients with Pancreas or Breast Adenocarcinoma. The Journal of Immunology, 169, 2756-2761. http://dx.doi.org/10.4049/jimmunol.169.5.2756

[78] deLeeuw, R.J., Kost, S.E., Kakal, J.A., et al. (2012) The Prognostic Value of FoxP3 ${ }^{+}$Tumor-Infiltrating Lymphocytes in Cancer: A Critical Review of the Literature. Clinical Cancer Research, 102, 345-352. http://dx.doi.org/10.1158/1078-0432.ccr-11-3216

[79] Martin, F., Ladoire, S., Mignot, G., et al. (2010) Human FOXP3 and Cancer. Oncogene, 29, 4121-4129. http://dx.doi.org/10.1038/onc.2010.174

[80] Tanchot, C., Terme, M., Pere, H., et al. (2012) Tumor-Infiltrating Regulatory T Cells: Phenotype, Role, Mechanism of Expansion in Situ and Clinical Significance. Cancer Microenvironment, 6, 147-157. http://dx.doi.org/10.1007/s12307-012-0122-y

[81] Ladoire, S., Martin, F. and Ghiringhelli, F. (2011) Prognostic Role of FOXP3 ${ }^{+}$Regulatory T Cells Infiltrating Human Carcinomas: The Paradox of Colorectal Cancer. Cancer Immunology, Immunotherapy, 60, 909-918. http://dx.doi.org/10.1007/s00262-011-1046-y

[82] Ghoreschi, K., Laurence, A., Yang, X.P., et al. (2010) Generation of Pathogenic $\mathrm{T}_{\mathrm{H}} 17$ Cells in the Absence of TGFBeta Signalling. Nature, 467, 967-971. http://dx.doi.org/10.1038/nature09447

[83] Baratelli, F., Lee, J.M., Hazra, S., et al. (2010) PGE(2) Contributes to TGF-Beta Induced T Regulatory Cell Function in Human Non-Small Cell Lung Cancer. American Journal of Translational Research, 2, 356-367.

[84] Willimsky, G. and Blankenstein, T. (2005) Sporadic Immunogenic Tumours Avoid Destruction by Inducing T-Cell Tolerance. Nature, 437, 141-146. http://dx.doi.org/10.1038/nature03954

[85] Savage, P.A., Malchow, S. and Leventhal, D.S. (2013) Basic Principles of Tumor-Associated Regulatory T Cell Biology. Trends in Immunology, 34, 33-40. http://dx.doi.org/10.1016/j.it.2012.08.005 
[86] Fontenot, J.D., Rasmussen, J.P., Williams, L.M., et al. (2005) Regulatory T Cell Lineage Specification by the Forkhead Transcription Factor Foxp3. Immunity, 22, 329-341. http://dx.doi.org/10.1016/j.immuni.2005.01.016

[87] Getnet, D., Grosso, J.F., Goldberg, M.V., et al. (2010) A Role for the Transcription Factor Helios in Human CD4 CD25 ${ }^{+}$Regulatory T Cells. Molecular Immunology, 47, 1595-1600. http://dx.doi.org/10.1016/j.molimm.2010.02.001

[88] Thornton, A.M., Korty, P.E., Tran, D.Q., et al. (2010) Expression of Helios, an Ikaros Transcription Factor Family Member, Differentiates Thymic-Derived from Peripherally Induced Foxp3 ${ }^{+}$T Regulatory Cells. The Journal of Immunology, 184, 3433-3441. http://dx.doi.org/10.4049/jimmunol.0904028

[89] Malchow, S., Leventhal, D.S., Nishi, S., et al. (2013) Aire-Dependent Thymic Development of Tumor-Associated Regulatory T Cells. Science, 339, 1219-1224. http://dx.doi.org/10.1126/science.1233913

[90] Paiva, R.S., Lino, A.C., Bergman, M.L., et al. (2013) Recent Thymic Emigrants Are the Preferential Precursors of Regulatory T Cells Differentiated in the Periphery. Proceedings of the National Academy of Sciences of the United States of America, 110, 6494-6499. http://dx.doi.org/10.1073/pnas.1221955110

[91] Vence, L., Palucka, A.K., Fay, J.W., et al. (2007) Circulating Tumor Antigen-Specific Regulatory T Cells in Patients with Metastatic Melanoma. Proceedings of the National Academy of Sciences of the United States of America, 104, 20884-20889. http://dx.doi.org/10.1073/pnas.0710557105

[92] Szajnik, M., Czystowska, M., Szczepanski, M.J., et al. (2010) Tumor-Derived Microvesicles Induce, Expand and Up-Regulate Biological Activities of Human Regulatory T Cells (Treg). PLOS ONE, 5, e11469. http://dx.doi.org/10.1371/journal.pone.0011469

[93] Wehrens, E.J., Mijnheer, G., Duurland, C.L., et al. (2011) Functional Human Regulatory T Cells Fail to Control Autoimmune Inflammation Due to PKB/c-akt Hyperactivation in Effector Cells. Blood, 118, 3538-3548. http://dx.doi.org/10.1182/blood-2010-12-328187

[94] Quintana, F.J., Iglesias, A.H., Farez, M.F., et al. (2010) Adaptive Autoimmunity and Foxp3-Based Immunoregulation in Zebrafish. PLOS ONE, 5, e9478. http://dx.doi.org/10.1371/journal.pone.0009478

[95] Samstein, R.M., Josefowicz, S.Z., Arvey, A., et al. (2012) Extrathymic Generation of Regulatory T Cells in Placental Mammals Mitigates Maternal-Fetal Conflict. Cell, 150, 29-38.

[96] Maury, S., Lemoine, F.M., Hicheri, Y., et al. (2010) CD4 $4^{+} \mathrm{CD} 25^{+}$Regulatory T Cell Depletion Improves the Graftversus-Tumor Effect of Donor Lymphocytes after Allogeneic Hematopoietic Stem Cell Transplantation. Science Translational Medicine, 2, 41-52.

[97] Dons, E.M., Raimondi, G., Cooper, D.K.C., et al. (2010) Non-Human Primate Regulatory T Cells: Current Biology and Implications for Transplantation. Transplantation, 90, 811-816. http://dx.doi.org/10.1097/TP.0b013e3181ebf782

[98] Hanahan, D. and Weinberg, R.A. (2011) Hallmarks of Cancer: The Next Generation. Cell, 144, 646-674. http://dx.doi.org/10.1016/j.cell.2011.02.013

[99] Koebel, C.M., Vermi, W., Swann, J.B., et al. (2007) Adaptive Immunity Maintains Occult Cancer in an Equilibrium State. Nature, 450, 903-924. http://dx.doi.org/10.1038/nature06309

[100] Menetrier-Caux, C., Curiel, T., Faget, J., et al. (2012) Targeting Regulatory T Cells. Targeted Oncology, 7, 15-28. http://dx.doi.org/10.1007/s11523-012-0208-y

[101] Yamaguchi, T., Wing, J.B. and Sakaguchi, S. (2011) Two Modes of Immune Suppression by Foxp3 ${ }^{+}$Regulatory T Cells under Inflammatory or Non-Inflammatory Conditions. Seminars in Immunology, 23, 424-430. http://dx.doi.org/10.1016/j.smim.2011.10.002

[102] Miyao, T., Floess, S., Setoguchi, R., et al. (2012) Plasticity of Foxp3(+) T Cells Reflects Promiscuous Foxp3 Expression in Conventional T Cells but Not Reprogramming of Regulatory T Cells. Immunity, 36, 262-275. http://dx.doi.org/10.1016/j.immuni.2011.12.012

[103] Elkord, E., Sharma, S., Burt, D.J. and Hawkins, R.E. (2011) Expanded Subpopulation of FoxP3 ${ }^{+}$T Regulatory Cells in Renal Cell Carcinoma Co-Express Helios, Indicating They Could Be Derived from Natural but Not Induced Tregs. Clinical Immunology, 140, 218-222. http://dx.doi.org/10.1016/j.clim.2011.04.014 